\title{
Ocena wytrzymałościowa stali mostów historycznych w świetle badań nieniszczących
}

\author{
Strength assessment of structural steels \\ in historic bridges by NDT
}

\section{Streszczenie}

Przeanalizowano właściwości wytrzymałościowe stali 30 mostów, wyznaczone dwoma sposobami. Sposobem bezpośrednim, polegającym na przeprowadzeniu badań niszczących 35 elementów konstrukcyjnych z 22 mostów oraz sposobem pośrednim nieniszczącym - poprzez badania twardości metodą Brinella 41 elementów z 27 mostów. Dwadzieścia badanych mostów wybudowano w drugiej połowie XIX wieku, a pozostałe dziesięć w XX wieku. Ocenę wytrzymałościową stali obiektów historycznych przeprowadzono w zależności od zawartości węgla w ich składach chemicznych. Wyznaczono zmodyfikowane współczynniki obliczeniowe ułatwiające określanie granicy plastyczności $R_{e B}$ sposobem nieniszczącym.

Słowa kluczowe: most stalowy; stal historyczna; twardość Brinella; wytrzymałość stali

\section{Abstract}

Tensile properties of steel in 30 bridges, determined in two ways, are presented. By the direct way, conducting destructive testing on 35 structural members from 22 bridges and by the indirect way - developing Brinell hardness testing to 41 members from 27 bridges. Twenty tested bridges were constructed in the second half of XIX century and the remaining ten were constructed in XX century. The strength assessment of historic steels is carried out taking into account the carbon content according to chemical analysis. Modified coefficients for easy estimation of a yield strength $R_{e B}$ are determined.

Keywords: steel bridge; historic steel; Brinell hardness; strength of steel

\section{Wstęp}

Przy ocenie starych stalowych obiektów budowlanych należy dokładnie rozpoznać gatunek stali w celu oszacowania jej parametrów wytrzymałościowych. Stosuje się dwa sposoby określania parametrów wytrzymałościowych: bezpośredni na podstawie próby statycznego rozciągania próbek pobranych z konstrukcji lub pośredni na podstawie pomiarów twardości Brinella $[1,2]$. Gdy brak jest możliwości pobrania próbek z istniejącej konstrukcji do niszczących badań wytrzymałościowych, jesteśmy zmuszeni do korzystania z nieniszczących pomiarów twardości [3]. Ten sposób pomiaru umożliwia pozyskanie stosunkowo dużej liczby wyników oraz umożliwia łatwą kontrolę jednorodności użytych gatunków stali zastosowanych do budowy obiektu. Dotyczy to w szczególności mostów remontowanych lub modernizowanych (rys. 1). W mostach z rysunku 1, w chwili obecnej, konstrukcje poszczególnych przęseł są wykonane z czterech gatunków stali o zróżnicowanych właściwościach wytrzymałościowych [4,5].

Według wycofanej normy PN-H-04357:1993 [6], metoda nieniszcząca szacowania parametrów wytrzyma-
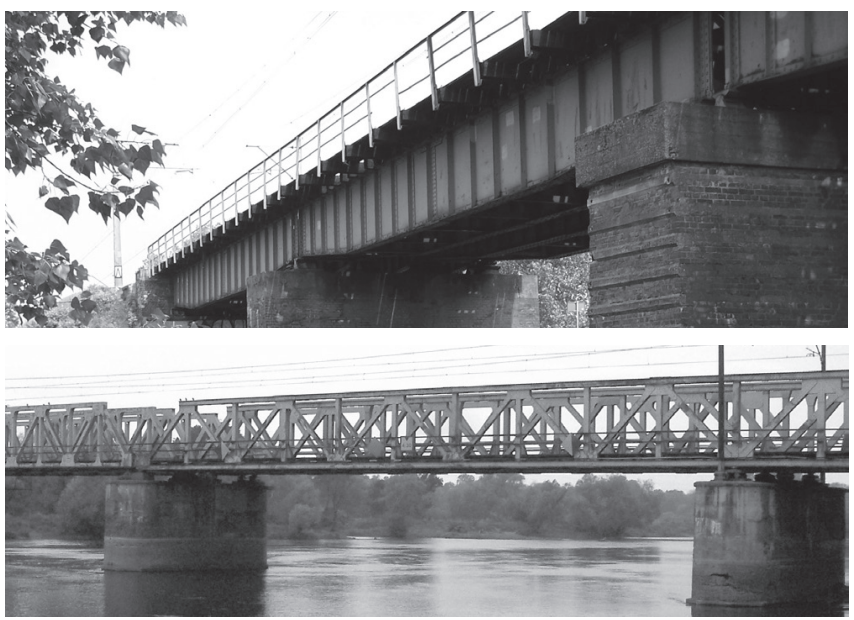

Rys. 1. Mosty kolejowe o zróżnicowanych gatunkach stali: a) most z roku 1873 na linii nr 353, nad Zbiornikiem Pakoskim koło miejscowości Janikowo [4], b) most z roku 1875 na linii nr 273, nad Wartą w Kostrzynie nad Odrą [5]

Fig. 1. Railroad bridges with differentiated steel grades a) bridge from year 1873 on railroad line $\mathrm{N}^{\circ} 353$ over the Pakoski Reservoir near Janikowo [4], b) bridge from year 1875 on railroad line $N^{\circ} 273$ over the Warta River in Kostrzyn over the Oder [5]

Dr inż. Janusz Hołowaty, dr hab. inż. Bernard Wichtowski - Zachodniopomorski Uniwersytet Technologiczny w Szczecinie. Autor korespondencyjny/Corresponding author: jah@wp.pl 
łościowych na podstawie twardości stali jest metodą przybliżoną (orientacyjną) i stosowaną w przypadkach, gdy nie można z badanego elementu pobrać próbki na rozciąganie $[7 \div 9]$. Stosowano ją tylko za zgodą zamawiającego. Celem artykułu jest oszacowanie przydatności tej nieniszczącej metody do identyfikacji parametrów wytrzymałościowych stali starych mostowych obiektów historycznych o zróżnicowanych składach chemicznych i zróżnicowanych parametrach mechanicznych. Jest to najczęściej stal niewiadomego pochodzenia o pozanormatywnych właściwościach.

\section{Pośrednie wyznaczanie wytrzymałości stali}

W 1900 r. August Brinell, szwedzki inżynier metalurg, podał dla stali węglowych, niehartowanych, zależność fenomenologiczną między wytrzymałością na rozciąganie $R_{m}$ i twardością HB równą [10]:

$$
R_{m}=0,347 \cdot \mathrm{HB} \cdot 9,81=3,404 \mathrm{HB}
$$

Inni autorzy, w wyniku licznych badań, podali następujące zależności:

- stal o twardości $125<\mathrm{HB}<175$

$\rightarrow R_{m} \approx 0,343 \cdot 9,81 \cdot \mathrm{HB}=3,365 \cdot \mathrm{HB}$

- stal o twardości HB > 175

$\rightarrow R_{m} \approx 0,362 \cdot 9,81 \cdot \mathrm{HB}=3,551 \cdot \mathrm{HB}$

Autorzy artykułu [8] dla polskiej stali gatunku St3S, 10HA i 18G2, o twardościach HB = 133 $\div 153$, uzyskali poniższe zależności średnie wyznaczone na drodze regresji liniowej:

$$
\begin{gathered}
R_{m}=3,315 \mathrm{HB} \\
R_{e}=2,305 \mathrm{HB}, \operatorname{przy} \alpha=R_{e} / R_{m}=0,695
\end{gathered}
$$

Normy [2,6] podają zależności (1) w postaci ogólnego wzoru:

$$
R_{m}=a_{m} \mathrm{HB}
$$

gdzie: współczynnik $a_{m}$ zależy od stosunku granicy plastyczności $R_{e H}$ do wytrzymałości na rozciąganie $R_{m}$, czyli $R_{e H} / R_{m}$. Ze wzrostem tego stosunku od 0,5 do 0,9 współczynnik $a_{m}$ zmniejsza się w przybliżeniu od 3,53 do 3,33. W normie [2] podano porównanie twardości HB i wytrzymałości na rozciąganie $R_{m}$ w zależności od trzech zakresów stosunku $\alpha=R_{e H} / R_{m}=$ poniżej 0,65 ; od 0,65 do 0,80 i powyżej 0,80 . Zamieszczono także wartości średnie wytrzymałości na rozciąganie przy współczynniku $a_{m}=3,37$, których przyjmowanie zaleca się, gdy nie jest znany stosunek $\alpha=R_{e H} / R_{m}$.

W publikacjach $[7,8]$ dla badanych trzech gatunków stali współczesnych uzyskano prawie jednakowe wartości $\alpha=0,710 ; 0,705$ i 0,695 dla stali o zawartości węgla około $0,16 \div 0,18 \%$. Różnica między wartościami obliczeniowej granicy plastyczności tych stali nie przekraczała $4 \%$, natomiast wytrzymałości na rozciąganie $10 \%$.

W stalach elementów mostów historycznych występuje bardziej zróżnicowany skład chemiczny i właściwości mechaniczne. Oznacza to, że porównywanie zależności między twardością a wytrzymałością $R_{m}$ wg pozycji $[7,8]$ z danymi dla stali obiektów historycznych jest trudniejsze. Próbę takiego szacowania przedstawiono w [11]. Stale w elementach starych mostów charakteryzują się większą niejednorodnością wytrzymałości niż stale produkowane współcześnie.

\section{Właściwości stali starych mostów}

Podczas ekspertyz technicznych przebadano stale 30 mostów, dla których ustalono ich rok budowy. Zestawienie tych obiektów w układzie chronologicznym ich powstania przedstawiono w tablicach I i II [12]. Dwadzieścia mostów zostało wybudowanych w drugiej połowie XIX wieku, a pozostałe $10 \mathrm{w}$ XX wieku. W tablicy I podano skład chemiczny stali 24 elementów konstrukcyjnych z analizowanych obiektów. W 17 przypadkach skład chemiczny określono metodą spektrometryczną, a w 7 przypadkach metodą "mokrą". Łatwo zauważyć duży rozrzut zawartości poszczególnych pierwiastków w badanych stalach. Zawartość trzech podstawowych pierwiastków wynosi: węgla od 0,016 do ok. 0,30\%, manganu od 0,24 do $1,64 \%$, a krzemu od 0,00 do $0,911 \%$. Powyższe wartości pierwiastków stopowych stali świadczą, że wszystkie mosty z drugiej połowy XIX wieku zostały wykonane ze stali zlewnej nieznanego gatunku, a stale mostów XX wieku z gatunku: St37•21, St34・12, St52, St3M i 18G2A.

Uzyskane duże zróżnicowanie zawartości węgla, w stalach przedmiotowych mostów, świadczy o ich zróżnicowanych właściwościach wytrzymałościowych i technologicznych (rys. $2 \mathrm{wg}$ [13]). Wytrzymałość i twardość rosną ze wzrostem zawartości węgla, natomiast ciągliwość, odporność na pękanie, podatność na odkształcenia plastyczne, spawalność i skrawalność - maleją (tabl. II). Węgiel jest pierwiastkiem najmocniej zwiększającym wytrzymałość oraz twardość i głównie w tym celu był stosowany w stali.

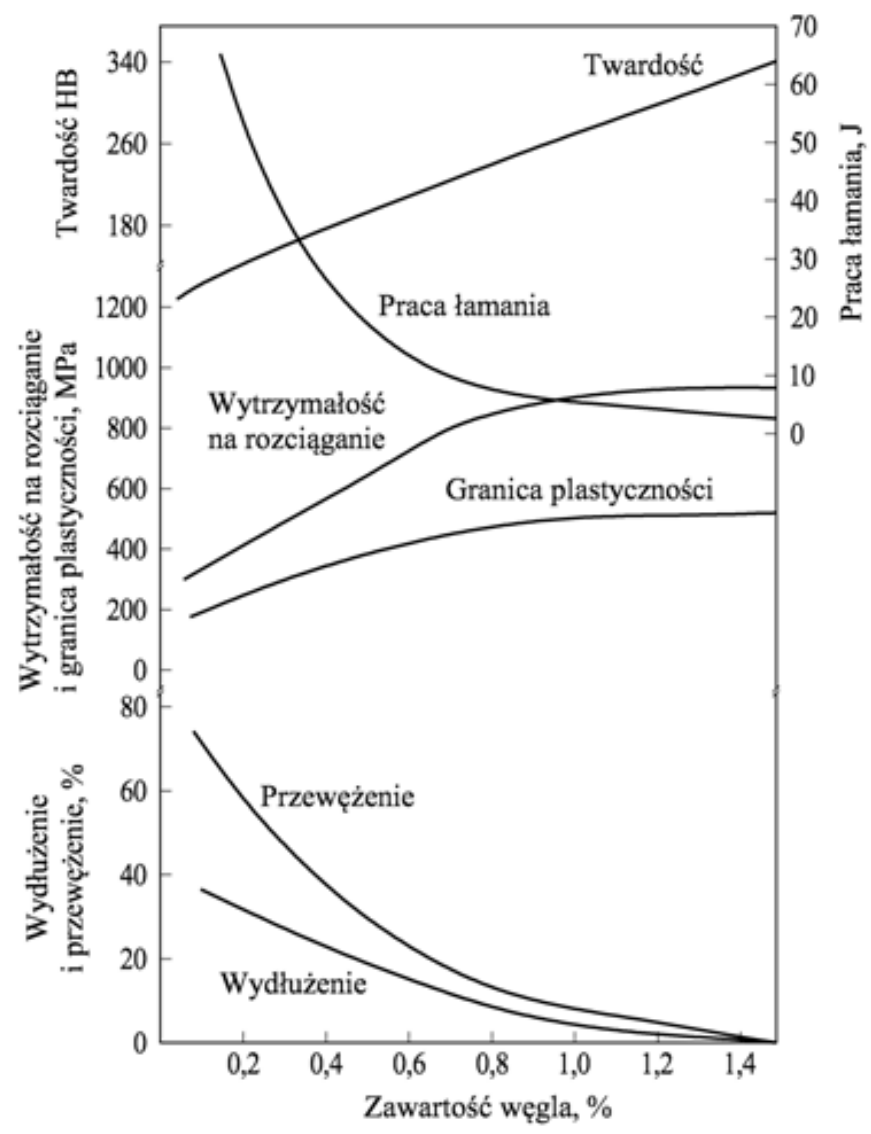

Rys. 2. Wpływ zawartości węgla na właściwości mechaniczne stali niestopowej

Fig. 2. Effect of carbon content on mechanical properties of nonalloy steel 
Tablica I. Skład chemiczny stali jednego mostu drogowego (nr 1) i 29 mostów kolejowych

Table I. Chemical composition of steel of a road bridge $\left(\mathrm{N}^{\circ} 1\right)$ and 29 railway bridges

\begin{tabular}{|c|c|c|c|c|c|c|c|c|c|c|}
\hline \multirow{2}{*}{$\begin{array}{l}\text { Numer } \\
\text { mostu }\end{array}$} & \multirow{2}{*}{$\begin{array}{c}\text { Rok } \\
\text { budowy }\end{array}$} & \multicolumn{9}{|c|}{ Zawartość pierwiastka [\%] } \\
\hline & & C & Mn & $\mathrm{Si}$ & $\mathbf{P}$ & s & $\mathrm{Cu}$ & $\mathrm{Cr}$ & $\mathrm{Ni}$ & Al \\
\hline 1 & 1857 & 0,035 & 0,450 & 0,001 & 0,022 & 0,011 & 0,033 & 0,000 & 0,156 & 0,008 \\
\hline 2 & 1873 & 0,130 & 0,535 & 0,010 & 0,048 & 0,032 & - & - & - & - \\
\hline 3 & 1875 & 0,045 & 0,538 & 0,000 & 0,017 & 0,025 & 0,178 & 0,020 & 0,104 & 0,000 \\
\hline 4 & 1875 & 0,233 & 0,685 & 0,178 & 0,036 & 0,041 & 0,140 & 0,019 & 0,045 & 0,000 \\
\hline 5 & 1875 & 0,299 & 0,984 & 0,182 & 0,020 & 0,028 & 0,158 & 0,019 & 0,033 & 0,000 \\
\hline 6 & 1875 & 0,258 & 0,591 & 0,192 & 0,026 & 0,043 & 0,241 & 0,025 & 0,136 & 0,000 \\
\hline 7 & 1875 & 0,138 & 1,085 & 0,911 & 0,024 & 0,043 & 0,441 & 0,021 & 0,066 & 0,005 \\
\hline 8 & 1875 & 0,147 & 1,409 & 0,803 & 0,035 & 0,042 & 0,459 & 0,033 & 0,081 & 0,005 \\
\hline 9 & 1876 & 0,042 & 0,425 & 0,000 & 0,037 & 0,021 & 0,050 & 0,000 & 0,000 & 0,001 \\
\hline 10 & 1879 & 0,06 & 0,28 & 0,24 & 0,044 & 0,030 & - & - & - & - \\
\hline 11 & 1879 & 0,07 & 0,24 & 0,20 & 0,101 & 0,033 & - & - & - & - \\
\hline 12 & 1879 & 0,08 & 0,29 & 0,20 & 0,090 & 0,042 & - & - & - & - \\
\hline 13 & 1882 & 0,030 & 0,319 & 0,004 & 0,031 & 0,024 & 0,051 & 0,010 & 0,037 & 0,002 \\
\hline 14 & 1882 & 0,033 & 0,497 & 0,000 & 0,041 & 0,017 & 0,206 & 0,013 & 0,017 & 0,000 \\
\hline 15 & 1885 & 0,074 & 0,390 & 0,000 & 0,028 & 0,015 & 0,126 & 0,000 & 0,030 & 0,007 \\
\hline 16 & 1885 & 0,177 & 0,736 & 0,000 & 0,035 & 0,072 & 0,100 & 0,000 & 0,030 & 0,003 \\
\hline \multirow{2}{*}{17} & \multirow{2}{*}{1887} & 0,028 & 0,516 & 0,000 & 0,062 & 0,025 & 0,051 & 0,000 & 0,042 & 0,004 \\
\hline & & 0,037 & 0,528 & 0,000 & 0,088 & 0,042 & 0,051 & 0,000 & 0,035 & 0,003 \\
\hline 18 & 1888 & 0,038 & 0,357 & 0,000 & 0,011 & 0,023 & 0,202 & 0,000 & 0,112 & 0,007 \\
\hline \multirow{2}{*}{19} & \multirow{2}{*}{1888} & 0,078 & 0,323 & 0,000 & 0,028 & 0,032 & 0,027 & 0,000 & 0,030 & 0,092 \\
\hline & & 0,031 & 0,370 & 0,000 & 0,100 & 0,027 & 0,008 & 0,000 & 0,031 & 0,016 \\
\hline \multirow{2}{*}{20} & \multirow{2}{*}{1890} & 0,033 & 0,756 & 0,001 & 0,033 & 0,013 & 0,033 & 0,000 & 0,160 & 0,006 \\
\hline & & 0,016 & 0,644 & 0,000 & 0,040 & 0,016 & 0,029 & 0,000 & 0,170 & 0,007 \\
\hline \multirow{2}{*}{21} & \multirow{2}{*}{1907} & 0,20 & 0,48 & 0,02 & 0,019 & 0,024 & - & - & - & - \\
\hline & & 0,142 & 0,333 & 0,012 & 0,051 & 0,051 & 0,066 & 0,268 & 0,220 & 0,006 \\
\hline 22 & 1925 & 0,15 & 0,43 & 0,01 & 0,045 & 0,034 & - & - & - & - \\
\hline 23 & 1928 & 0,196 & 1,250 & 0,378 & 0,022 & 0,016 & 0,063 & 0,223 & 0,001 & 0,002 \\
\hline 24 & 1935 & 0,060 & 0,470 & 0,006 & 0,035 & 0,016 & 0,040 & 0,050 & 0,051 & 0,003 \\
\hline 25 & 1935 & 0,150 & 0,390 & 0,006 & 0,015 & 0,032 & 0,110 & 0,030 & 0,050 & 0,001 \\
\hline 26 & 1935 & 0,140 & 0,540 & 0,006 & 0,044 & 0,038 & 0,140 & 0,020 & 0,010 & ślad \\
\hline 27 & 1938 & 0,084 & 0,460 & 0,045 & 0,006 & 0,026 & 0,156 & 0,018 & 0,031 & 0,035 \\
\hline 28 & 1950 & 0,18 & 1,23 & 0,31 & 0,050 & 0,019 & - & - & - & - \\
\hline 29 & 1983 & 0,140 & 0,676 & 0,169 & 0,011 & 0,021 & 0,039 & 0,022 & 0,021 & 0,068 \\
\hline 30 & 1995 & 0,154 & 1,640 & 0,362 & 0,020 & 0,024 & 0,071 & 0,054 & 0,041 & 0,042 \\
\hline
\end{tabular}


Właściwości wytrzymałościowe i plastyczne stali 22 mostów określono na podstawie badań statycznego rozciągania próbek (rys. 3). Natomiast wytrzymałość na rozciąganie $R_{m}$ stali 8 mostów określono na podstawie pomiarów twardości Brinella, próbek wyciętych z elementów do badań chemicznych. Poza tym w 9 mostach, w przypadku 10 elementów, oprócz badań próbek z materiału w stanie aktualnym, czyli zestarzonym samorzutnie, badano próbki poddane dodatkowemu wyżarzaniu normalizacyjnemu (wartość w nawiasach). Próbki te wygrzewano w temperaturze $930{ }^{\circ} \mathrm{C}$ przez jedną godzinę i studzono na powietrzu. Uzyskuje się w tym przypadku najmniejszą możliwą wielkość ziarna. Określone parametry mechaniczne tych próbek są porównywalne z właściwościami stali w fazie dostawy, czyli z okresu budowy mostu.

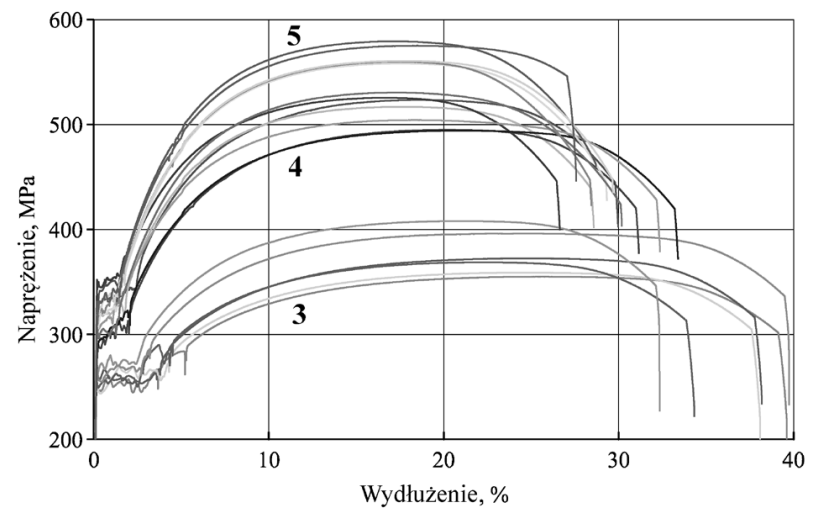

Rys. 3. Wykresy rozciągania 18 próbek stali mostów $\mathrm{nr} 3,4$ i 5 (C = 0,045\%; $C=0,233 \%$ i C $=0,300 \%$ )

Fig. 3. Tensile curves of 18 specimens of steel from bridges 3,4 and $5(\mathrm{C}=0.045 \% ; \mathrm{C}=0.233 \%$ and $\mathrm{C}=0.300 \%)$

Uzyskane wyniki badań stali 33 elementów analizowanych 30 mostów przedstawiono w tablicy II. Uzyskano duży rozrzut wyników wartości $R_{e H}$ i $R_{m}$. Granica plastyczności $R_{\text {eH }}$ wynosi od 218 do $380 \mathrm{MPa}$ (mosty nr 20 i 23), a granica wytrzymałości na rozciąganie $R_{m}$ od 350 do $587 \mathrm{MPa}$ (mosty nr 10 i 23). Jednocześnie współczynnik $\alpha=R_{e H} / R_{m}$ jest zróżnicowany od 0,58 do 0,79 (mosty nr 5 i 11). Procentowe zróżnicowanie powyższych wartości w odniesieniu do wartości minimalnej wynosi $R_{e H}-74,3 \%, R_{m}-78,2 \%$ i $\alpha-36,2 \%$. Graficzne zobrazowanie zależności $\alpha$ od zawartości węgla przedstawiono na rysunku 4.
W tablicy II oprócz wyników badań statycznego rozciągania próbek z 22 elementów konstrukcyjnych z 19 mostów, przedstawiono również ich wyniki z badań twardości metodą Brinella. Badania przeprowadzono twardościomierzem typ B3Cs w tzw. warunkach standardowych, a ich średnie wyniki z co najmniej trzech pomiarów podano $\mathrm{w}$ kolumnie 7 tablicy II. Zachowano oznaczenie twardości jako HB, a nie HBW wg PN-EN ISO 6506, ponieważ jako wgłębnik stosowano kulkę stalową, a nie z węglika spiekanego. Używano kulki stalowej $D=5$ lub $10 \mathrm{~mm}$, przy obciążeniu $P=7350$ lub $29430 \mathrm{~N}$, utrzymywanym przez $t=15 \mathrm{~s}$.

Dla wyznaczonych twardości HB stali próbek z poszczególnych mostów, w zależności od $\emptyset$ odcisku, określano z normy wytrzymałości na rozciąganie $R_{m B}$ (kol. 8, tabl. II). Dla badanych mostów obliczone wartości współczynnika am, ze wzoru (1), = $R_{m B} / \mathrm{HB}$, przyjmują wartości od 3,356 do 3,328 i różnią się od wartości 3,404 jedynie o-1,41 i -2,23\%. Oznacza to, że również określone wartości $R_{m}$ i $R_{m B}$ różnią się nieznacznie. Granica wytrzymałości $R_{m B}$ wynosi od 345 do $604 \mathrm{MPa}$ (mosty nr 21 i 23) i różni się od granicznych wartości $R_{m}$ jedynie o -1,43 $\mathrm{i}+2,90 \%$.

Trudności występują przy określaniu wartości $R_{e B}=\alpha \cdot R_{m B}$, z uwagi na znaczną rozpiętość, dla omawianych mostów, wartości $\alpha=0,58 \div 0,79$ (por. tabl. II). Zróżnicowane wartości $\alpha$ uzależnione są od zawartości węgla wg rysunku 4. W artykule [3] podano, dla stali w elementach starych mostów, wartości współczynnika $\alpha_{B}$ W funkcji zawartości węgla, wg poniższych zależności:

$$
\begin{array}{ll}
C<0,02 \% & \rightarrow \alpha_{B}=0,64 \\
C=0,02 \div 0,05 \% & \rightarrow \alpha_{B}=0,70 \\
C=0,05 \div 0,10 \% & \rightarrow \alpha_{B}=0,75 \\
C=0,10 \div 0,15 \% & \rightarrow \alpha_{B}=0,69 \\
C=0,15 \div 0,20 \% & \rightarrow \alpha_{B}=0,65 \\
C=0,20 \div 0,28 \% & \rightarrow \alpha_{B}=0,64 \\
C>0,28 \% & \rightarrow \alpha_{B}=0,60
\end{array}
$$

Przyjmując współczynniki $\alpha_{B}$ z kolumny 9 tablicy II, obliczono wartości granicy plastyczności $R_{e B}$, zamieszczone w kolumnie 10. Wartości $R_{e B}$ wynoszą od 244 do $380 \mathrm{MPa}$ (mosty nr 21 i 22 oraz 23) i różnią się od granicznych wartości $R_{\mathrm{eH}} \mathrm{O}+11,9$ i $0 \%$. Natomiast dla poszczególnych mostów wartości skrajne ilorazu $R_{\mathrm{eB}} / R_{\mathrm{eH}}$ wynoszą 0,84 i 1,15 (mosty nr 20 i 22 oraz 27).

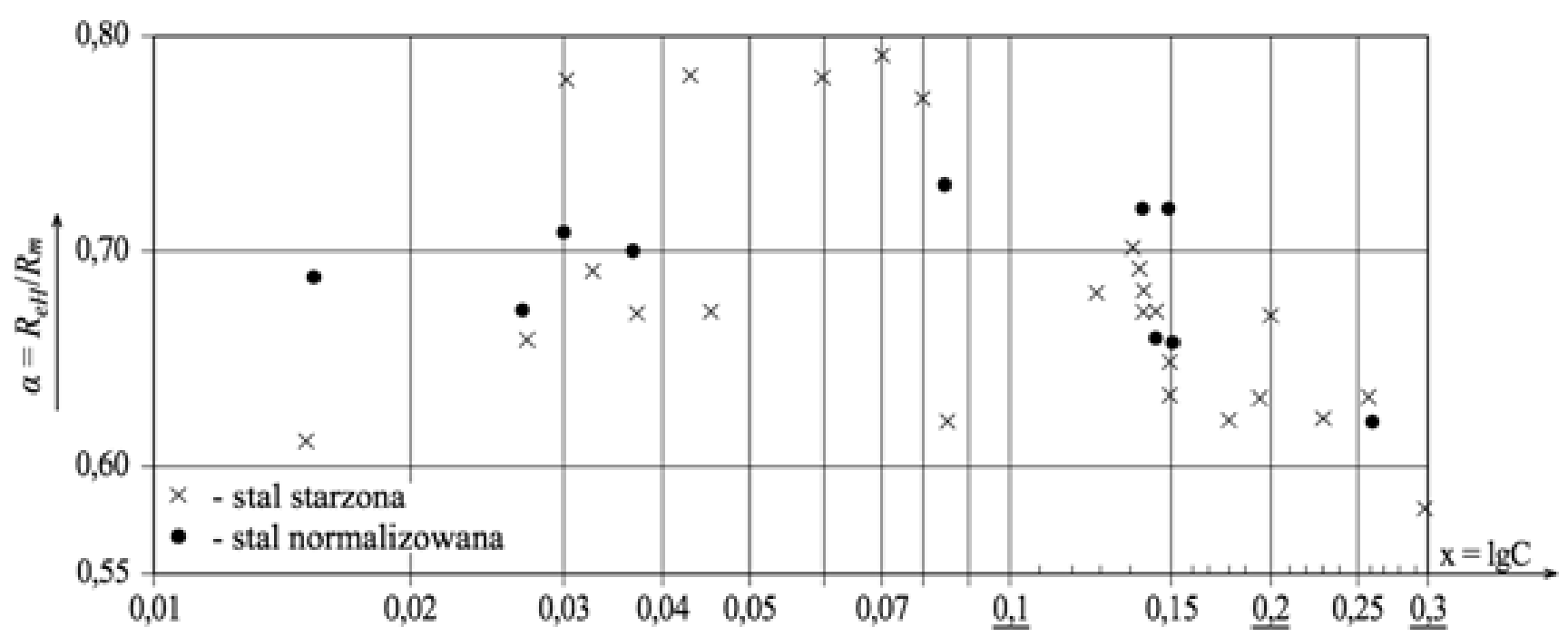

Rys. 4. Wartości $\alpha$ w zależności od zawartości węgla dla 25 elementów

Fig. 4. The value of $\alpha$ depending on the carbon content for 25 elements 
Tablica II. Parametry mechaniczne stali mostów z XIX i XX wieku

Table II. Mechanical properties of steel from XIX ${ }^{\text {th }}$ and $X X^{\text {th }}$ century bridges

\begin{tabular}{|c|c|c|c|c|c|c|c|c|c|c|c|}
\hline \multirow{2}{*}{$\begin{array}{l}\text { Numer } \\
\text { mostu }\end{array}$} & \multirow{2}{*}{$\begin{array}{c}\text { Rok } \\
\text { budowy }\end{array}$} & \multirow{2}{*}{$\begin{array}{c}\text { C } \\
{[\%]}\end{array}$} & \multirow{2}{*}{$\begin{array}{c}\mathbf{R}_{\mathrm{eH}} \\
{[\mathrm{MPa}]}\end{array}$} & \multirow{2}{*}{$\begin{array}{c}\mathbf{R}_{\mathrm{m}} \\
{[\mathrm{MPa}]}\end{array}$} & \multirow{2}{*}{$\begin{array}{c}a=\mathbf{R}_{\mathrm{eH}} / \\
\mathbf{R}_{\mathbf{m}}\end{array}$} & \multicolumn{4}{|c|}{ Twardość Brinella stali } & \multirow{2}{*}{$\begin{array}{l}\mathbf{R}_{\mathrm{eH}} \\
\mathbf{R}_{\mathrm{eB}}\end{array}$} & \multirow{2}{*}{$\begin{array}{l}\mathbf{R}_{\mathrm{m}} \\
\mathbf{R}_{\mathrm{mB}}\end{array}$} \\
\hline & & & & & & HB & $\mathbf{R}_{\mathrm{mB}}$ & $a_{B}$ & $\mathbf{R}_{\mathrm{eB}}$ & & \\
\hline 1 & 1857 & 0,035 & - & - & - & 114 & 383 & 0,70 & 268 & - & - \\
\hline 2 & 1873 & 0,130 & 271 & 393 & 0,69 & 113 & 387 & 0,70 & 271 & 1,00 & 1,02 \\
\hline 3 & 1875 & 0,045 & 253 & 376 & 0,67 & 111 & 375 & 0,70 & 262 & 0,97 & 1,00 \\
\hline 4 & 1875 & 0,233 & 318 & 510 & 0,62 & 146 & 488 & 0,62 & 307 & 1,04 & 1,05 \\
\hline 5 & 1875 & 0,299 & 322 & 560 & 0,58 & 160 & 537 & 0,58 & 311 & 1,04 & 1,04 \\
\hline 6 & 1875 & 0,258 & $\begin{array}{c}343 \\
(337)\end{array}$ & $\begin{array}{c}548 \\
(543)\end{array}$ & $\begin{array}{c}0,63 \\
(0,62)\end{array}$ & $\begin{array}{c}152 \\
(151)\end{array}$ & $\begin{array}{c}507 \\
(504)\end{array}$ & $\begin{array}{c}0,63 \\
(0,63)\end{array}$ & $\begin{array}{c}319 \\
(317)\end{array}$ & $\begin{array}{c}1,08 \\
(1,06)\end{array}$ & $\begin{array}{c}1,08 \\
(1,08)\end{array}$ \\
\hline 7 & 1875 & 0,138 & 380 & 548 & 0,69 & 152 & 509 & 0,70 & 356 & 1,07 & 1,08 \\
\hline 8 & 1875 & 0,147 & $\begin{array}{c}376 \\
(365)\end{array}$ & $\begin{array}{c}558 \\
(554)\end{array}$ & $\begin{array}{c}0,67 \\
(0,66)\end{array}$ & $\begin{array}{c}159 \\
(160)\end{array}$ & $\begin{array}{c}531 \\
(537)\end{array}$ & $\begin{array}{c}0,67 \\
(0,67)\end{array}$ & $\begin{array}{c}356 \\
(360)\end{array}$ & $\begin{array}{c}1,06 \\
(1,01)\end{array}$ & $\begin{array}{c}1,05 \\
(1,03)\end{array}$ \\
\hline 9 & 1876 & 0,042 & 327 & 421 & 0,78 & 122 & 406 & 0,78 & 317 & 1,03 & 1,04 \\
\hline 10 & 1879 & 0,06 & 273 & 350 & 0,78 & - & - & - & - & - & - \\
\hline 11 & 1879 & 0,07 & 294 & 370 & 0,79 & - & - & - & - & - & - \\
\hline 12 & 1879 & 0,08 & 304 & 396 & 0,77 & - & - & - & - & - & - \\
\hline 13 & 1882 & 0,030 & $\begin{array}{c}305 \\
(265)\end{array}$ & $\begin{array}{c}389 \\
(376)\end{array}$ & $\begin{array}{c}0,78 \\
(0,71)\end{array}$ & $\begin{array}{c}121 \\
(114)\end{array}$ & $\begin{array}{c}404 \\
(383)\end{array}$ & $\begin{array}{c}0,70 \\
(0,70)\end{array}$ & $\begin{array}{c}283 \\
(268)\end{array}$ & $\begin{array}{c}1,08 \\
(0,99)\end{array}$ & $\begin{array}{c}0,96 \\
(0,98)\end{array}$ \\
\hline 14 & 1882 & 0,033 & - & - & - & 118 & 395 & 0,70 & 276 & - & - \\
\hline 15 & 1885 & 0,074 & - & - & - & 111 & 375 & 0,75 & 281 & - & - \\
\hline 16 & 1885 & 0,177 & - & - & - & 143 & 479 & 0,65 & 311 & - & - \\
\hline \multirow{2}{*}{17} & \multirow{2}{*}{1887} & 0,028 & $\begin{array}{c}252 \\
(260) \\
\end{array}$ & $\begin{array}{c}381 \\
(388) \\
\end{array}$ & $\begin{array}{c}0,66 \\
(0,67) \\
\end{array}$ & $\begin{array}{c}116 \\
(126)\end{array}$ & $\begin{array}{c}389 \\
(418)\end{array}$ & $\begin{array}{c}0,70 \\
(0,70) \\
\end{array}$ & $\begin{array}{c}272 \\
(292)\end{array}$ & $\begin{array}{c}0,93 \\
(0,89) \\
\end{array}$ & $\begin{array}{c}0,98 \\
(0,93)\end{array}$ \\
\hline & & 0,037 & $\begin{array}{c}259 \\
(285)\end{array}$ & $\begin{array}{c}387 \\
(408)\end{array}$ & $\begin{array}{c}0,67 \\
(0,70)\end{array}$ & $\begin{array}{c}121 \\
(132)\end{array}$ & $\begin{array}{c}405 \\
(441) \\
\end{array}$ & $\begin{array}{c}0,70 \\
(0,70)\end{array}$ & $\begin{array}{c}283 \\
(308)\end{array}$ & $\begin{array}{c}0,92 \\
(0,93)\end{array}$ & $\begin{array}{c}0,96 \\
(0,93)\end{array}$ \\
\hline 18 & 1888 & 0,038 & - & - & - & 110 & 367 & 0,70 & 257 & - & - \\
\hline \multirow{2}{*}{19} & \multirow{2}{*}{1888} & 0,078 & - & - & - & 124 & 412 & 0,75 & 309 & - & - \\
\hline & & 0,031 & - & - & - & 121 & 405 & 0,70 & 283 & - & - \\
\hline \multirow[b]{2}{*}{20} & \multirow[b]{2}{*}{1890} & 0,033 & 258 & 372 & 0,69 & 123 & 409 & 0,70 & 286 & 0,90 & 0,91 \\
\hline & & 0,016 & $\begin{array}{c}218 \\
(258) \\
\end{array}$ & $\begin{array}{c}359 \\
(373) \\
\end{array}$ & $\begin{array}{c}0,61 \\
(0,69)\end{array}$ & $\begin{array}{c}117 \\
(115) \\
\end{array}$ & $\begin{array}{c}392 \\
(386) \\
\end{array}$ & $\begin{array}{c}0,64 \\
(0,64) \\
\end{array}$ & $\begin{array}{c}251 \\
(247) \\
\end{array}$ & $\begin{array}{c}0,87 \\
(1,04)\end{array}$ & $\begin{array}{c}0,92 \\
(0,97)\end{array}$ \\
\hline \multirow{2}{*}{21} & \multirow{2}{*}{1907} & 0,20 & 283 & 420 & 0,67 & 111 & 375 & 0,65 & 244 & 1,16 & 1,12 \\
\hline & & 0,142 & 298 & 425 & 0,70 & 102 & 345 & 0,78 & 269 & 1,11 & 1,23 \\
\hline 22 & 1925 & 0,15 & $\begin{array}{c}244 \\
(325)\end{array}$ & $\begin{array}{c}376 \\
(448)\end{array}$ & $\begin{array}{c}0,65 \\
(0,72)\end{array}$ & $\begin{array}{c}98 \\
(109)\end{array}$ & $\begin{array}{c}339 \\
(378)\end{array}$ & $\begin{array}{c}0,72 \\
(0,72)\end{array}$ & $\begin{array}{c}244 \\
(272)\end{array}$ & $\begin{array}{c}1,00 \\
(1,19)\end{array}$ & $\begin{array}{c}1,11 \\
(1,19)\end{array}$ \\
\hline 23 & 1928 & 0,196 & 371 & 587 & 0,63 & 179 & 604 & 0,63 & 380 & 0,98 & 0,97 \\
\hline 24 & 1935 & 0,060 & - & - & - & 129 & 430 & 0,63 & 271 & - & - \\
\hline 25 & 1935 & 0,150 & $\begin{array}{c}268 \\
(289) \\
\end{array}$ & $\begin{array}{c}423 \\
(440) \\
\end{array}$ & $\begin{array}{c}0,63 \\
(0,66) \\
\end{array}$ & $\begin{array}{c}121 \\
(116) \\
\end{array}$ & $\begin{array}{c}426 \\
(408) \\
\end{array}$ & $\begin{array}{c}0,63 \\
(0,63) \\
\end{array}$ & $\begin{array}{c}268 \\
(257) \\
\end{array}$ & $\begin{array}{c}1,00 \\
(1,12) \\
\end{array}$ & $\begin{array}{c}0,99 \\
(1,08) \\
\end{array}$ \\
\hline 26 & 1935 & 0,140 & 262 & 386 & 0,68 & 112 & 378 & 0,65 & 246 & 1,06 & 1,02 \\
\hline 27 & 1938 & 0,084 & $\begin{array}{c}220 \\
(275) \\
\end{array}$ & $\begin{array}{c}356 \\
(376) \\
\end{array}$ & $\begin{array}{c}0,62 \\
(0,73) \\
\end{array}$ & $\begin{array}{c}107 \\
(106) \\
\end{array}$ & $\begin{array}{r}362 \\
(357) \\
\end{array}$ & $\begin{array}{c}0,70 \\
(0,70) \\
\end{array}$ & $\begin{array}{c}253 \\
(250) \\
\end{array}$ & $\begin{array}{c}0,87 \\
(1,10) \\
\end{array}$ & $\begin{array}{c}0,98 \\
(1,05) \\
\end{array}$ \\
\hline 28 & 1950 & 0,18 & 363 & 585 & 0,62 & 174 & 583 & 0,63 & 367 & 0,99 & 1,00 \\
\hline 29 & 1983 & 0,140 & $\begin{array}{c}286 \\
(328) \\
\end{array}$ & $\begin{array}{c}430 \\
(456)\end{array}$ & $\begin{array}{c}0,67 \\
(0,72)\end{array}$ & $\begin{array}{c}118 \\
(121)\end{array}$ & $\begin{array}{c}396 \\
(426)\end{array}$ & $\begin{array}{c}0,70 \\
(0,70)\end{array}$ & $\begin{array}{c}277 \\
(298)\end{array}$ & $\begin{array}{c}1,03 \\
(1,10)\end{array}$ & $\begin{array}{c}1,09 \\
(1,07)\end{array}$ \\
\hline 30 & 1995 & 0,154 & - & - & - & 170 & 569 & 0,63 & 358 & - & - \\
\hline
\end{tabular}




\section{Podsumowanie}


elementów przedmiotowych mostów od 0,016 do 0,30\%. Tak znaczne zróżnicowanie procentowej zawartości węgla (prawie dziewiętnastokrotne) oraz znaczna liczba badanych elementów (42) pozwoliła wyznaczyć zróżnicowane wartości współczynnika $\alpha_{B}=R_{e} / R_{m}$ wykorzystywanego przy szacowaniu wytrzymałości stali na podstawie twardości. Słuszność takiego postępowania potwierdzają wartości granicy plastyczności $R_{e H}$ uzyskane z badań statycznego rozciągania stali i z badań twardości HB. Występujące maksymalne różnice wynoszą (po odrzuceniu dwóch wartości skrajnych) od -10 do $+12 \%$, Duże zróżnicowanie zawartości węgla w stalach mostowych pozwoliło ocenić jego wpływ na właściwości badanych stali (tabl. II). Wytrzymałość i twardość zwiększają się wraz ze wzrostem zawartości węgla w stali.

Przy ocenie właściwości mechanicznych stali obiektów historycznych sposobem pośrednim - poprzez badanie twardości Brinella, należy uwzględnić wpływ zawartości węgla w jej składzie chemicznym.

\section{Literatura}

[1] PN-EN ISO 6892-1:2010 Metale - Próba rozciągania - Część 1: Metoda badania w temperaturze pokojowej.

[2] PN-EN ISO 6506-4:2014 Metale - Pomiar twardości sposobem Brinella Część 4: Tablice wartości twardości.

[3] B. Wichtowski, J. Hołowaty: Analiza właściwości materiałowych i spawalności stali zlewnej mostów kolejowych, Inżynieria i Budownictwo, LXIX(5), s. 247-251, 2013.

[4] B. Wichtowski, J. Hołowaty: Ocena właściwości stali konstrukcyjnych modernizowanego mostu na linii kolejowej nr 353, Inżynieria i Budownictwo, LXX(8), s. 429-434, 2014.

[5] J. Hołowaty, B. Wichtowski: Problemy spawalnicze przy modernizacji starych mostów kolejowych, Przegląd Spawalnictwa, Vol. 87(5), s. 45-51, 2015.

[6] PN-H-04357:1993 Stal i staliwo - Tablice porównawcze twardości określonej sposobem Rockwella, Vickersa, Brinella, Shore'a i wytrzymałości na rozciaganie.

[7] J. Dudkiewicz, B. Gosowski: Wykorzystanie nieniszczących badań twardości do oceny wytrzymałości stali w konstrukcjach budowlanych, Inżynieria i Budownictwo, LXII(1), s. 49-55, 2006.
[8] B. Gosowski, P. Organek, M. Redecki: Bezpośrednie i pośrednie wyznaczanie wytrzymałości obliczeniowej stali w konstrukcjach budowlanych, Materiały Budowlane, 499(3), s. 56-59, 2014.

[9] A. Biegus, J. Dudkiewicz, O. Kozioł, P. Organek: Ocena wytrzymałości obliczeniowej dawnych stali na podstawie pomiarów twardości Brinella Inżynieria i Budownictwo, LXXI(10), s. 520-524, 2015.

[10] S. Błażewski, J. Mikoszewski: Pomiary twardości metali, WNT, Warszawa, 1981.

[11] J. Dudkiewicz, B. Gosowski, P. Organek: Assessing the strength and weIdability of historic structural steel, Civil and Environmental Engineering Reports, Vol. 18(3), s. 33-42, 2015

[12] B. Wichtowski: Badania parametrów mechanicznych stali w istniejących konstrukcjach stalowych, XXXI Ogólnopolskie WPPK Naprawy i wzmocnienia konstrukcji budowlanych, tom III, Szczyrk 2016.

[13] M. Blicharski: Inżynieria materiałowa. Stal, WNT, Warszawa, 2004. 